\title{
ASUHAN KEBIDANAN PADA IBU NIFAS DENGAN PUTING SUSU TERBENAM GRADE I DI BPM PRAPTI VIDIANINGSIH KOTA PEKANBARU TAHUN 2019
}

\author{
Miratu Megasari, Mutiara Amelia \\ STIKes Hang Tuah Pekanbaru \\ Miratu090586@htp.ac.id
}

\begin{abstract}
Grade I milking nipples are nipples that are pulled in so that they are easy to pull out and last quite well. From the data obtained by the 2015 Mangkubumi Tasikmalaya Community Health Center, mothers who did not breastfeed counted 120 people, 63 of whom were not breastfeeding because the nipples were immersed.

The method used in this case study with the midwifery management approach was then documented in the form of SOAP and to overcome the nipples of immersed milk problems it was deemed necessary to provide midwifery care for breast care, teaching how to breastfeed properly. Case taking was carried out at BPM Prapti Vidianingih and at the patient's home.

In this case study the authors carried out midwifery care for postpartum mothers with immersed nipples as much as 2 visits with a 5 day lag by providing information, education about immersion nipples care \& teaching mothers syringe techniques \& good and correct suckling positions. So in getting the result of postpartum mothers with grade 1 milk nipples the good expenditure of breast milk so that breast milk expenditure still exists.

It is expected that the BPM Prapti Vidianingsih will counsel about immersed nipples and teach the correct way of breast care, how to overcome the immersed nipples in a simple way, and teach correct breastfeeding techniques
\end{abstract}

Keywords: Midwifery,Care, Postpartum, Inherited Milk Putting,Grade I.

\section{INTISARI}

Puting susu terbenam Grade I adalah Puting yang tertarik kedalam sehingga mudah untuk ditarik keluar dan bertahan cukup Baik. Dari data yang didapat Puskesmas Mangkubumi Tasikmalaya 2015 ibu yang tidak menyusui terhitung 120 orang, 63 orang diantaranya tidak menyusui dikarenakan putting susu terbenam. Selama masa nifas puting susu terbenam dapat di atasi dengan cara perawatan yang dilakukan terhadap payudara bertujuan untuk melancarkan sirkulasi darah dan mencegah tersumbatnya saluran susu sehingga mempelancar pengeluaran ASI.

Metode yang digunakan pada studi kasus ini dengan pendekatan manajemen kebidanan kemudian di dokumentasikan dalam bentuk SOAP dan untuk mengatasi masalah putting susu terbenam dirasa perlu dilakukan asuhan kebidanan perawatan payudara, mengajarkan cara menyusui yang baik dan benar. Pengambilan kasus 
dilaksanakan di BPM Prapti Vidianingih dan di rumah pasien. Pada studi kasus ini penulis melakukan asuhan kebidanan pada ibu nifas dengan putting susu terbenam sebanyak 2 kali kunjungan dengan jeda waktu 5 hari dengan memberikan informasi,edukasi tentang perawatan putting susu terbenam \& mengajarkan ibu teknik spuit \& posisi menyusu yang baik dan benar.

Maka di dapatkan hasil ibu nifas dengan puting susu terbenam grade 1 pengeluaran ASI yang baik sehingga pengeluaran ASI tetap ada.

Bagi tenaga kesehatan diharapkan melakukan konseling tentang puting susu terbenam dan mengajarkan cara perawatan payudara yang benar, cara mengatasi puting susu terbenam dengan cara sederhana, dan mengajarkan teknik menyusui yang benar mengunakan media poster/liflaet.

Kata Kunci : : Asuhan,Kebidanan, Nifas, Puting Susu Terbenam,Grade I.

\section{PENDAHULUAN}

Pencapaian ASI Eksklusif di Indonesia masih tergolong rendah, berdasarkan data Riskesdas 2010, angka pemberian ASI eksklusif bagi bayi yang berusia dibawah 6 bulan adalah sebesar $15,3 \%$. Bayi yang menggunakan susu formula mencapai $27,9 \%$. Pemberian ASI eksklusif di 51 negara berdasarkan pengukuran indikator yang telah ditetapkan, Indonesia rangking ke 37 dari 51 negara (Tauriska \& Umamah, 2015). Puting susu terbenam adalah puting yang tampak masuk kedalam areola sebagian atau seluruhnya (Nugroho, 2011).

Data yang diperoleh dari Kemkes RI Menujukan bahwa persentasi bayi baru lahir yang mendapatkan inisiasi menyusui dini (IMD) dan bayi mendapatkan ASI Eksklusif pada tahun 2016 di provinsi Riau masih rendah yaitu $42,2 \%$, cakupan bayi yang mendapatkan
IMD dan 39,7\% bayi yang mendapatkan ASI Eksklusif sampai usia bayi 6 bulan, angka ini jauh lebih rendah dibandingkan dengan prsentasi yang dicapai oleh provinsi Nanggroe Aceh Darussalam yaitu cakupan IMD 57,8\% dan prsentasi yang mendapatkan ASI Eksklusif sampai usia 6 bulan adalah 59\%, hal ini perlu menjadi perhatian kita (Kemkes RI, 2016).

Kegagalan IMD dapat terjadi karna faktor dari bidan dan faktor dari ibu, faktor dari ibu bisa dikarnakan adanya kelainan anatomi pada payudara dan ketidak siapan ibu dalam peroses IMD kelainan anatomi salahsatunya adalah yaitu puting susu yang terbenam dan kolostrum yang tidak keluar, sehingga bayi sulit untuk mencapai puting susu ibunya apalagi untuk menghisapnya (Ramadhanti, 2015).

Menurut Yayuk Norazizah dan Luluk Hidayah (2013) dalam Maulani 
(2016) selama masa nifas puting susu terbenam dapat di atasi dengan cara Perawatan yang dilakukan terhadap payudara bertujuan untu kmelancarkan sirkulasi darah dan mencegah ter sumbatnya saluran susu sehingga mempelancar pengeluaran ASI. Pelaksanaan perawatan payudara hendaknya dimulai sedini mungkin yaitu 1-2 hari setelah bayi dilahirkan dan dilakukan dua kali sehari. Perawatan payudara yang dilakukan meliputi pengurutan payudara, pengosongan payudara, pengompresan payudara dan perawatan puting susu. Menurut Dewi (2011) dalam Maulani (2016) untuk mencegah timbulnya infeksi atau komplikasi pada masa nifas utamanya dengan puting susu terbenam dan ASI tidak keluar dilakukan dengan peningkatan mutu pelayanan kesehatan.

Menurut hasil penelitian Maulani (2016), Berdasarkan hasil survei di Puskesmas Mangkubumi Kota Tasikmalaya jumlah ibu nifas tahun 2015 terhitung dari bulan Januari-Desember sebanyak 906 orang. Diantaranya terdapat ibu menyusui pada tahun 2015 terhitung dari bulan Januari-Desember sebanyak 495 orang. Sedangkan ibu yang tidak menyusui terhitung 120 orang, dikarena salahsatunya faktor ASI tidak keluar sebanyak 36 orang dan puting susu terbenam sebanyak 63 orang.

Berdasarkan hasil data yang didapatkan dari BPM Prapti Vidianingsih kasus puting susu terbenam sekitar 3 orang dalam satu tahun ini. Kasus ini dapat di atasi dengan cara Perawatan yang dilakukan terhadap payudara bertujuan untuk melancarkan sirkulasi darah dan mencegah tersumbatnya saluran susu sehingga mempelancar pengeluaran ASI. Berdasarkan keterangan diatas tersebut penulis merasa tertarik untuk mengangkat kasus dengan judul “Asuhan Kebidanan pada Ibu Nifas dengan Puting Susu Terbenam di BPM Prapti Vidianingsih Tahun $2019 "$.

\section{METODE KASUS}

Menurut Notoatmodjo (2010) metode pengambilan studi kasus dilakukan dengan cara meneliti suatu permasalahan melalui suatu kasus yang terdiri dari unit tunggal. Unit yang menjadi kasus tersebut secara mendalam dianalisis baik dari segi yang berhubungan dengan keadaan kasus itu sendiri, faktor-faktor yang mempengaruhi, kejadian-kejadian khusus yang muncul sehubung dengandengan kasus, maupun tindakan dan reaksi kasus terdapat usatu perlakuan atau pemaparan tertentu. 
WAKTU DAN LOKASI

Dilaksanakan di BPM Prapti Vidianingsih Pekanbaru yang dilakukan tanggal 2-8 Juli 2019

\section{a. Data Subjektif}

1. Puting susu sudah sedikit menonjol dari sebelumnya tetapi belum mau menyusu, ibu melakukan teknik spuit 2x sehari untuk membantu puting susu menonjol.

2. Ingin ber KB suntik 3 bulan saat usia anak 6 bulan.

\section{b. Data Objektif}

Keadaan umum ibu : Compos mentis, Tekanan darah: 110/70 mnhg, Pernapasan: $20 \mathrm{x} / \mathrm{menit}$, Denyut nadi : $84 \mathrm{x} /$ menit, Suhu: $36,3{ }^{0} \mathrm{C}$, Puting susu: Sebelah kanan menonjol, sebelah kiri terbenam.

c. Analisis

$\mathrm{P} 2 \mathrm{~A} 0 \mathrm{H} 2$ nifas 5 minggu dengan

Puting Susu Terbenam Grade 1

\section{d. Penatalaksanaan}

1. Kondisi pasien

2. Istirahat yang cukup

3. Pola hidup sehat

4. Tanda bahaya masa nifas.

\section{PEMBAHASAN}

\section{Kajian I}

\section{a. Data subjektif}

Masa nifas (pueperium) dimulai setelah pelasenta lahir dan berakhir ketika alat-alat kandung kembali seperti keadaan sebelum hamil, masa nifas berlangsung selama 6 minggu atau 42 hari (Maritalia, 2012) Pada Kunjungan nifas pertama dilakukan pada tanggal: 02 Juli 2019 pukul: 19.30 Wib di rumah pasien.

Penulis melakukan pengkajian pada ibu nifas dengan pengumpulan identitas yaitu mengumpulkan semua data yang dibutuhkan untuk informasi yang akurat, penulis telah mngumpulkan identitas pasien yaitu Ny. L berusia 24 Tahun, beragama islam, pendidikan terakhir SMA, pekerjaan ibu sebagai IRT. Beralamat di J1.Pepaya Sukajadi.

Setelah identitas didapatkan, penulis mengumpulkan semua informasi yang akurat dari semua sumber yang berkaitan dengan kondisi pasien ataupun keluhan pasien yang dirasakannya yang disebut sebagai data subyektif (Handayani, 2017). Penulis telah mengumpulkan data subjektif bahwa Ibu mengatakan puting susu ibu tidak menonjol, ibu mengatakan bayi tidak diberikan 
susu formula, bayi mau menyusu di payudara sebelah kanan ibu namun kemudian setelah dipindahkan ke payudara kiri ibu bayi menolak untuk disusui karena puting susu ibu tidak menonjol sehingga bayi tidak dapat menyusu dengan baik. Keluhan pada kasus Ny. L lazim dijumpai pada ibu menysusui yaitu puting susu terbenam.Kasus putting susu terbenam banyak dijumpai pada ibu nifas. Menurut penelitian Maulani (2016) berdasarkan hasil survei di Puskesmas Mangkubumi Kota Tasikmalaya jumlah ibu yang tidak menyusui terhitung 120 orang, dikarena salah satunya faktor puting susu terbenam yaitu sebanyak 63 orang.

\section{b. Data objektif}

Dalam praktik kebidanan data subjektif harus didasari oleh data objektif, data objektif yaitu untuk memastikan bahwa keadaan klien dalam keadaan stabil, yang termasuk dalam kompenenkompenen data objektif yaitu TTV, pemeriksaan fisik, data penunjang (Handayani, 2017). Penulis telah melakukan pemeriksaan data objektif berupa keadaan umum ibu baik, kesadaran composmentis, tekanan darah : 110/70 mmHg, Nadi : 88 $\mathrm{x} / \mathrm{i}$, Pernafasan : $20 \mathrm{x} / \mathrm{i}$, Suhu : $37,1{ }^{0} \mathrm{C}$. Pemeriksaan mamae ASI sudah ada, puting susu terbenam grade I, benjolan tidak ada, ibu tidak merasakan nyeri pada payudara. Ciri- ciri puting susu terbenam grade 1 ialah puting tertarik kedalam tapi mudah untuk ditarik keluar dan bertahan cukup Baik.

\section{c. Assesment}

Data subjektif dan objektif telah dikumpulkan, membuat kesimpulan terhadap kondisi pasien atas data-data yang telah dikumpulkan, dalam langkah ini data yang telah dikumpulkan di intepretasikan menjadi diagnosa kebidanan dan masalah yang dialami pasien (Handayani, 2017). Penulis menengakan diagnosa sesuai data yang didapat kan yaitu $\mathrm{P}_{2} \mathrm{~A}_{0} \mathrm{H}_{2}$ nifas 5 minggu dengan puting susu terbenam grade I.

\section{d. Plan}

\begin{tabular}{|c|c|c|}
\hline & Menurut & (Muslihatun, \\
\hline 2009) & Planning & mengambarkan \\
\hline dok & umentasian & tindakan dan \\
\hline evaluas & & perencar \\
\hline implem & nentasi & berdasar \\
\hline
\end{tabular}


pengumpulan data sujektif, objektif, dan assasment sesuai kebutuhan pasien. Planning pada kasus ini penulis memberikan pendidikan kesehatan tentang putting susu terbenam, jadi untuk mengatasi putting susu terbenam tersebut maka perlu dilakukan asuhan kebidanan pada putting susu terbenam

Menurut Yayuk Norazizah dan Luluk Hidayah (2013) dalam Maulani (2016) selama masa nifas puting susu terbenam dapat di atasi dengan cara Perawatan yang dilakukan terhadap payudara bertujuan untuk melancarkan sirkulasi darah dan mencegah ter sumbatnya saluran susu sehingga mempelancar pengeluaran ASI. Perawatan payudara yang dilakukan meliputi pengurutan payudara.

Cara menyusui yang benar Menurut Walyani \& Purwoastuti (2015) adalah posisi yang tepat bagi ibu untuk menyusui. Duduklah dengan posisi yang nyaman atau santai, pakailah kursi yang ada sandaran punggung dan lengan. Gunakan bantal untuk mengganjal bayi agar bayi tidak terlalu jauh dari payudara ibu.
Dalam mengenai puting susu terbenam grade I penulis mengajarkan teknik spuit menurut teori Wiji (2013) yaitu dengan cara: a). Menempelkan ujung pompa / spuit pada payudara sehingga puting berada di dalam pompa. b). Tarik perlahan sehingga terasa ada tekanan dan di pertahankan selama 30 detik 1 menit, bila terasa sakit tarikan dapat dikendorkan, asi yang keluar dimasukan kecangkir. Dapat dilakukan sesuai kebutuhan.

\section{Kajian II}

\section{a. Data subjektif}

Penulis Melakukan kunjungan ulang bertujuan untuk menilai keadaan ibu dan bayi baru lahir dan untuk mencegah mendeteksi dan menangani masalah-masalah yang terjadi, seorang bidan pada saat meberikan asuhan kepada ibu dalam masa nifas ada beberapa hal yang harus dilakukan, akan tetapi pemberian asuhan kebidanan pada ibu masa nifas tergantung dari kondisi ibu sesuai dengan tahap perkembangannya, penulis melakukan Kunjungan nifas kedua pada tanggal : 8 Juli 2019 pukul : 19.30 Wib di rumah 
pasien.

PenuliS mengumpulkan semua informasi yang akurat dari semua sumber yang berkaitan dengan kondisi pasien ataupun keluhan pasien yang disebut data subyektif (Handayani, 2017). Melihat perkembangan dari keluhan kunjungan pertama apakah ada perubahan pada masalah ibu pada kunjungan kedua ini, penulis mendapatkan data subjektif bahwa puting susu sudah sedikit menonjol dari sebelumnya dan bayi belum bisa menyusu.

\section{b. Data objektif}

Setelah penulis melakukan pengumpulan data subjektif maka selanjtnya penulis melakuakan pengumpulan data objektif yaitu untuk memastikan bahwa keadaan klien dalam keadaan stabil, yang termasuk dalam kompenenkompenen data objektif yaitu TTV, pemeriksaan fisik, data penunjang (Permenkes 938 Tahun 2007). Data objektif yang didapat oleh penulis keadaan umum ibu baik, kesadaran composmentis, tekanan darah : 110/70 mmHg, Nadi : 84 x/i, Pernafasan : 20 x/i, Suhu : 36,3
${ }^{0} \mathrm{C}$. Pemeriksaan mamae ASI sudah ada, puting susu sebelah kanan menonjol, dan putting susu sebelah kiri terbenam memasuki grade 1 , benjolan tidak ada, rasa nyeri pada payudara tidak ada.

\section{c. Assesment}

Data subjektif dan objektif telah di kumpulkan, penulis selanjutnya mengidentifikasi diagnosa kebidanan dan masalah berdasarkan intepretasi yang benar- benar atas data-data yang telah dikumpulkan, dalam langkah ini data yang telah dikumpulkan diintepretasikan menjadi diagnosa kebidanan dan masalah yang dialami (Handayani, 2017). Penulis telah mengumpulakn data subjektif dan objektif penulis menengakan diagnosa sesuai data yang didaptkan dan masalah pada pasien yaitu $\mathrm{P}_{1} \mathrm{~A}_{0} \mathrm{H}_{1}$ nifas 38 hari dengan puting susu terbenam Grade 1.

\section{d. Plan}

Dari data subjektif penulis menemukan masalah pada ibu yaitu ibu dengan istirahat terganggu dan penulis memberikan penkes Menurut buku Kesehatan RI (2015) untuk 
mengatur istirahat ibu yang cukup menganjurkan ibu tidur saat bayi tidur agar pola tidur ibu tidak terganggu. Menurut Bahiyatun (2009) dalam Laura (2015) Pada masa postpartum, ibu membutuhkan istirahat dan tidur yang cukup. Menurut Sulistyawati, 2009 dalam Laura (2015) Kebutuhan istirahat bagi ibu menyusui minimal 8 jam sehari, yang dapat dipenuhi melalui istirahat malam dan siang.

Produksi ASI dapat diperbanyak dengan kebutuhan dan cairan menurut (Nugroho, Taufan) kebutuhan gizi pada masa nifas terutama pada ibu menyusui akan meningkat $25 \%$ untuk memproduksi air susu yang cukup untuk menyehatkan bayi, semua itu akan meningkat tiga kali dari kebutuhan biasa, menurut buku (Kementrian Kesehatan RI, 2015) yaitu makanan yang mengandung kabohidrat, protein hewani seperti mengkomsumsi telur, protein nabati, sayur dan buahbuahan,dan Kebutuhan air minum pada ibu menyusui pada 6 bulan pertama 14 gelas sehari, dan pada 6 bulan kedua 12 gelas perhari. Menurut teori Wiji (2013) makanan yang mempengaruhi produksi ASI termasuk mengkonsumsi kacang hijau baik itu yang direbus atau yang sudah dibuat bubur kacang hijau. Makanan ini mengandung vitamib B1, protein, Fosfor, tiamin, mangan, kalium, magnesium, asam folat. Selain mampu memproduksi banyak ASI, kacang hijau dapat mencangkup kebutuhan protein dan energi.

Berdasarkan Rencana Asuhan kunjungan nifas, penulis memberikan edukasi mengenai tanda bahaya masa nifas, hal ini sesuai dengan teori (Dewi, 2012) yaitu menilai adanya tanda-tanda bahaya pada pasca melahirkan, tanda bahaya pada masa nifas yaitu demam tinggi yang melebihi $38^{\circ} \mathrm{c}$, perdarahan yang berlebihan dan gumpalan darah yang besarbesar dan berbauk busuk, sakit kepala yang hebat.

\section{KESIMPULAN}

Asuhan kebidanan ibu nifas yaitu Ny. L di BPM Prapti Vidianingsih, Amd.Keb kemudian dilanjutkan dengan kunjungan rumah di dapatkan hasil bahwa selama 2 kali kunjungan, penulis tidak menemukan kesenjangan antara 
teori dan asuhan yang diberikan. Keluhan yang dirasakan ibu adalah merasa khawatir tidak bisa menyusui bayinya dikarenakan puting susunya terbenam. Dalam pemeriksaan selama 2 kali kunjungan mulai dari 5 minggu post partum sampai 6 minggu post partum, telah diberikan informasi dan asuhan yang menyeluruh tentang masa nifas salah satunya melakukan dan mengajarkan ibu cara perawatan payudara, melakukan dan mengajarkan ibu cara mengeluaran puting susu. Evaluasi asuhan kebidanan yang diberikan pada pasien Ny. L umur 24 tahun dengan puting susu terbenam grade I dapat menonjol dan pulih dalam waktu 5 hari, yaitu KU ibu menjadi baik, tanda-tanda vital dalam batas normal, warna lochea normal, tidak ada tanda-tanda bahaya masa nifas, bayi dapat menyusui dengan baik dan benar, ibu merasa senang dan nyaman dengan keadaannya, putting susu sudah menonjol. Sehingga dapat disimpulkan pada evaluasi antara teori dan kasus tidak terdapat kesenjangan.

\section{SARAN}

\section{Bagi BPM Prapti Vidianingsih,} Amd. Keb

Diharapkan bidan melakukan konseling tentang puting susu terbenam dan mengajarkan cara perawatan payudara yang benar, cara mengatasi puting susu terbenam dengan cara sederhana, dan mengajarkan teknik menyusui yang benar mengunakan media poster/liflaet.

\section{Bagi Instituti Pendidikan}

Diharapkan dapat menjadi referensi penelitian kebidanan berikutnya terutama tentang nifas, dan diharapkan sebagai tambahan pengetahuan bagi mahasiswa kebidanan dan mahasiswa mampu melakukan penanganan putting susu terbenam.

\section{Bagi Penulis Selanjutnya}

Diharapkan bagi penulis selanjutnya studi kasus ini dapat digunakan sebagai referensi dan bahan masukan dalam melakukan program studi kasus yang akan datang.

\section{DAFTAR PUSTAKA}

Dewi, V. (2012). Asuhan Kebidanan pada Ibu Nifas. Jakarta: Salemba Medika.

Fitriani. (2013). Gambaran Pengetahuan Ibu Hamil Tentang Perawatan Payudara Selama Kehamilan dan Pada Masa Nifas di RB Mattiro Baji Gowa Tahun 2013. m: 
Universitas Islam Negri Alauddin

Makassar. https://doi.org/page 20 Of 88

Kemkes RI. (2016). Profil Kesehatan Indonesia. Jakarta: Kementrisn Kesehatan Republik Indonesia.

Lecet, S., Bpm, D. I., \& Diwek, S. S.

T. K. (2017). ASUHAN KEBIDANAN PADA IBU NIFAS DENGAN PUTING ( Midwefery Care In The Post Partum Mothers With Nipple Blisters In Bpm Suhartini , Sst Sub-District Diwek Of Jombang District ) Erda Eliyanti , Mudhawaroh, Hexawan Tjahja Widada Stikes Pemkab Jombang Email :, 3(2).

Maritalia, D. (2012). Asuhan Kebidanan

Nifas dan Menyusui. Yogyakarta: Pustaka Pelajar.

Marmi. (2012). Asuhan

Kebidanan pada Masa Nifas

“Peuperium Care." Yogyakarta:

Pustaka Pelajar.

Maryunani, A. (2012). Inisiasi Menyusui Dini, Asi Ekslusif dan Manajemen Laktasi. Jakarta: CV. Trans Info media.

Maulani, S. (2016). Auhan Kebidanan Pada Ibu Nifas Dengan Putting Susu Tenggelam ( Grade 1 ) Dan
ASI Tidak Keluar di BPM $\mathrm{Hj}$. Wiwin Wintarsih, AM . Keb. Tasikmalaya: Sekolah Tinggi Ilmu Kesehatan Muhammadiyah Ciamis.

Notoatmodjo, S. (2010). Metodologi Penelitian Kesehatan. Jakarta: PT Rineka Cipta.

Nugroho, T. (2011). Asi dan Tumor Payudara. Yogyakarta: Nuha Medika.

Ramadhanti, I. (2015). Inisiasi Menyusui Dinidi Bidan Praktek Swsta Paulina Bukit Tinggi 2015, $7(1), 3$.

Suherni, dkk. (2009). Perawatan Masa Nifas (cet. 4). Yogyakarta: Citramaya.

Tauriska, T., \& Umamah, F. (2015). Hubungan Antara Isapan Bayi dengan Produksi ASI pada Ibu Menyusui di Rumah Sakit Islam 